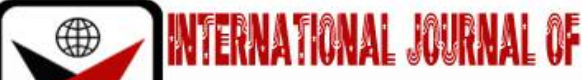

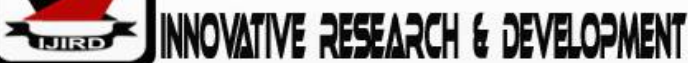

ISSN 2278-0211 (Online)

\section{Effect of Innovation on Competitive Advantage of Manufacturing Firms in Rwanda: A Case of Africa's Improved Food}

\author{
Uwase Grace \\ MBA Student, Department of Strategic Management, \\ Jomo Kenyatta University of Agriculture and Technology, Kigali, Rwanda \\ Dr. Patrick Mulyungi \\ Lecturer, School of Business Studies \\ Jomo Kenyatta University of Agriculture and Technology, Kigali, Rwanda
}

\begin{abstract}
:
Competitive advantages are conditions that allow a company or country to produce a good or service of equal value at a lower price or in a more desirable fashion. The objective of this study was to assess the determinants of competitive advantage for manufacturing firms in Rwanda. In this study; a descriptive research was adopted. The target population for this study was 64 senior staff; the researcher adopted a census since the population was quite small in numbers. Primary data was collected using questionnaires. Descriptive and inferential statistics were computed to assess the determinants of competitive advantage for manufacturing firms in Rwanda. Statistical Package for Social Scientists was used to execute multiple linear regressions. According to the results of correlation between innovations and competitive advantage of Africa Improved Foods is at the level of 0.789 meaning that the practice of making innovations which is measured in terms of developing new products to new markets, developing new products to existing markets, spending money in Research and Development and developing new capabilities to compete at the market influence the Return on investment, Market Share and Profitability of Africa Improved Food at the level of 78.9\%. Therefore, the study concluded a strong relationship between innovations and competitive advantage of Africa Improved Foods. By considering the level of significance which is 0.05, there is a significant relationship innovations and competitive advantage of Africa Improved Foods as their p-value (0.007) is statistically significant at 5\% level of significance. The study makes the following recommendations. Manufacturing firms in Rwanda; especially Africa Improved Foods Ltd should take the innovative spirit to the high level by increase the efforts in new products development, markets development and increase the more money in Research and Development so as to outperform its competitors.
\end{abstract}

Keywords: Innovation and competitive advantage of manufacturing

\section{Background of the Study}

The competitive strategies that are considered successful when there is a balance between the economic requirement imposed by global markets and the social requirement of a nation formed by history, tradition and value systems. Competitive enterprises are the key drivers in China competitiveness. They create the core of the economic development. But in a modern economy, nations do not rely solely on products and services, (Abdallah, G. M. Al, \&Muala, A. Al., 2012). The abilities of a nation to develop an excellent educational system and to improve their employment skills through training are vital for competitiveness. Manual defined innovation as an activity that leads to a product (good or service), which product is either new or significantly improved or made using a significantly improved process, a new marketing method or a new organizational method in business practices, workplace organization or external relationships, (Kumlu, Ö., 2014). Innovation is based on the results of new technologies, new combinations of existing technology or the use of other knowledge acquired by the enterprise. Probably, one of the biggest challenges for European countries, as shown by an important number of national and European documents, is to find a much more strategic approach to innovation, (Morgan, E. J., \& Crawford, N., 2003). Europe 2020 Flagship Initiative Innovation Union sustains an approach where innovation becomes a main political objective on a medium and long term perspective, where all policy instruments, measures and findings are designed to contribute to innovation, where China policies and national regional authorities are closely aligned and mutually reinforcing and where the highest political level sets a strategic agenda, monitors progress regularly and tackles delays. At a European level, the 'Innovation Union' initiative considers that it is necessary to build a different paradigm because the current one, 'business as usual', is equivalent to the gradual loss of 
China competitive advantages and the acceptance of Europe's decline. We could call it an 'innovation paradigm, (Bayarçelik, E. B., Taşel, F., \&Apak, S., 2014).

In Nigeria the innovation strategy has become a plan of how to use the development of new products, services, processes or business models to achieve certain objectives. Consequently, to create growth, sustain performance and develop performance in a dynamic and changing environment, innovation becomes the way (Cottam, Ensor \& Band, 2016). For a rapid economic growth in developing economies, entrepreneurship and industrial development are among valuable targets. While entrepreneurship is the mainstay of significant economic growth, it can only expect tangible results through innovation. Innovation refers to all scientific, technological, organizational, financial and commercial steps which actually lead to, or are intended to lead to, the implementation of technologically new or improved products or services (OECD, 2005). The OECD (2005) inventories four types of innovation: product innovations, process innovations, organizational innovations and marketing innovations.

A number of factors can affect innovation activities. These include economic factors such as production costs and demand, factors specific to an enterprise such as skilled personnel or knowledge, and legal factors such as competition regulations and tax rules (Crepon et al., 2014). Marques at al. (2011) stressed the fact that encouraging firms to innovate will lead to a better economic performance of firms in terms of market and financial performance. Thus, policy that promotes innovation may help fostering growth and competitiveness among business, specific regions and in the economy at large Based on Schumpeter's (2010) theory of creative destruction that proposes that non-innovative firms and products are replaced with innovative ones; Rwanda, similar to many regional and African countries has identified innovation to be a sustainable way to ensure high economic growth and enterprise performance (MINECOFIN, 2013). Although innovation is generally regarded as a means of improving the competitiveness of firms and their performance locally or regionally, it hasn't been supported unambiguously by empirical work in Rwanda.

Studies which link innovation to firm performance or that analyses determinants of firm innovativeness are yet few in developing countries. Especially, in Rwanda, on the best of our knowledge, no other similar study has been conducted. Thus, policy makers promote innovation may help fostering growth and competitiveness among business, specific on international markets and in the economy at large.

Africa Improved Food seems to have developed this advantage over its rivals like Inyange Industries, Urwibutso Enterprises and Sosoma Industries. This is evident from the fact that Africa Improved Food has posted exemplary results compared to its competitors for the last five years. In the year 2017, for example, African Improved Food had a net profit of 142 Billion Rwandan Francs (Africa Improved Food Annual report, 2017).

Innovation is understood in the sense of new products, new technologies, new equipment acquisitions, improved management or financial methods, the improved performance of the labor force, and the improved information system. Implementing innovation ensures competitive advantage (Lucia, 2012). Successful companies understand that to stay in the business and achieve profitability, they need to always innovate. Organizations can successfully create new products and services that delight customers and exceed market expectations if they develop functional innovation strategy that provides organizations with the framework for success, (Muscio, A., Nardone, G., \&Dottore, A., 2010).

Many firms in Rwanda can only achieve superior performance if it provides services or goods/ products which customers can pay for at a price that is higher than it costs the firm to produce/manufacture them. It is imperative that the firm must therefore create value to be able to achieve superior performance and have a competitive edge. Value creation is at the center of any successful strategy. However, value creation in itself is not enough. In order to prosper, the firm must be able to capture the value it creates. In order to create and capture value, the firm must have a sustainable competitive advantage, (Saunila, M., 2014).

\subsection{Statement of the Problem}

Africa Improved Food has been using several innovation strategies such as new brands, different packaging strategies and providing discounts to its esteemed customers, but however these strategies, innovation strategies are still poor in manufacturing firms of Rwanda especially in Africa Improved Food because all other competitors blueprints these mentioned above strategies, in addition to the statement, the performance of Africa Improved Food has been hindered due to the high competition from manufacturing companies. However Africa Improved food had been suffering from lacking skilled labor on the local market because the experts might be expensive in respect to organization budget, AIF had also been lacking raw materials for insistence the type of maize to be used in production of Nutri-Mama and Nutri-Toto is not presently sufficient because it is imported from Zambia which is costly and final products had also been a big problem. Therefore, a research has to be conducted and suggestions with results of findings has to be generated that is why the research entitled' Effect of Innovation on Competitive Advantage of Manufacturing Firms in Rwanda'.

\section{Literature Review}

\subsection{Innovation Theory}

Innovation theory was proposed by Rogers (2016). The theory presents that innovation is a process aimed to bring competitive advantages with organization. According to innovation diffusion theory, innovation is defined as an idea perceived as new by individuals. OECD (2014) cited by Andreanne and Swaminathan, (2017) defined innovation as „all the scientific, technological, organizational, financial, and commercial activities necessary to create, implement, and market new or improved products or processes Innovation theory brings on board four important elements". The first element is innovation that puts attention on the ability to come up with more efficient and better ways of doing things. 
This theory categorize adopters of innovation into five categories; innovators, individuals who want to be the first to try the innovation, Early Adopters, people who represent opinion leaders, Early Majority individuals who need to see evidence that the innovation works before they can adopt it, Late Majority, skeptical individuals who only adopts an innovation after it has been tried by the majority and Laggards, individuals who are very skeptical of change and are the hardest group to involve in the innovation process,(Wang, Y., \& Costello, P., 2009).

According to innovation theory, rate of adoption of innovative strategies can be looked at in terms of; relative advantage given to the organization, compatibility, complexity, trial-ability of the new strategies and observability to the stakeholders within the social system. The second factor is communication that lays information and creating and sharing information relating to innovative initiatives in the organization. The third element is time that considers the duration involved in the innovation-decision process. The last element is the social context of the new systems (Rogers, 2016). Diffusion of innovation strategies requires evolution and reinvention of products and people so that they are able to perform better (Les Robinson, 2014). The concepts in this theory are very relevant to this study. They help build on the study and enable the researcher understand the expected relationship between the variables. While innovation diffusion theory brings understanding of the innovation process, it has a number of limitations. The theory does not foster a participatory approach. It is therefore only able to work best with adoption of behaviors. Lastly, the theory does not take into account an organization's resources and social support in adoption of new methods, (Zhang, M., 2006).

\subsection{Conceptual Framework}

Refers to a theoretical structure of assumptions, principles, and rules that holds together the ideas comprising a broad concept. According to Miles and Huberman (2014), a conceptual framework explains, either graphically or in narrative form, the main things to be studied the key factors, constructs or variables and the presumed relationships among them.

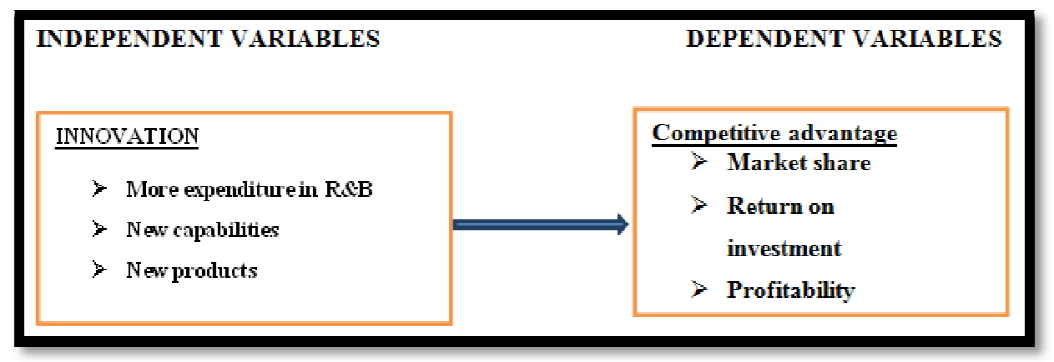

Figure 1: Conceptual Framework

Source: Researcher, 2020

Africa improved foods uses incremental innovation as they try to add value to the existing value of their products, the brand's line extensions such as nootri mama, nootritoto and more recently nootri family have enabled a Africa improved foods brand to stay relevant, tap into emerging trends and bring something new to its customers over the years, (Van Stel, A. 2013).

AIF has innovated through introducing line extensions. As well as developing new flavors, the brand has also created new formats, such as nootri youth, (MINECOFIN, 2013).

Incremental innovation doesn't just apply to products; it affects services too. AIF's has evolved its delivery service so that online shoppers can receive their goods more quickly. Just the other week, the online giant JUMIA announced that it was trialing same-day delivery - a move that will help the brand to meet rising customer needs. This type of innovation is common in manufacturing firms in Rwanda and had made Africa improved foods out compete the rest of competitors in the game, (Fritsch, M. and Mueller, P. 2014).

\subsection{Innovation and Competitive Advantage of a Manufacturing Firm}

Innovation and competitive advantage of manufacturing firms has different categories of innovation, Mairesse and Robin (2014) found that innovation appears to be the main driver of competitive advantage in the French manufacturing and service industries. Also, Legros and Galia (2012), analyzing the sources of knowledge and their effects on competitive advantage in French manufacturing, seems that the market share and firm size have a positive impact on innovation decision for of manufacturing firms.

Previous results confirm conclusions of Griffith et al. (2012) who studied the role that innovation plays in competitive advantage of manufacturing firms four European countries using a structural multistage model (Crepon et al., 2012). These countries are France, Germany, Spain and UK. They used data from the third wave of the internationally harmonized community innovation surveys. They found that firms that operate mainly in international markets and larger firms are more engaged in formal innovative activities for competitive advantage of firms. Furthermore, conclusions of Griffith et al. (2012) state that the process innovation is associated with competitive advantage only in France, while innovation is associated with competitive advantage in three countries, namely France, Spain and UK. Also, previous findings are supported by the conclusion of Zemplinerova and Hramadkova (2012) in Czechoslovakia. These authors found that probability to engage in innovation for a firm is positively influenced by its size for competing with other firms. While 'a good company' requires unsurpassed management, product quality, and financial soundness, the 'most admired' companies are presumed to also have a 'spark' that ignites the workforce and allows the enterprise to respond readily to 
change. That ingredient is innovation and all the top companies embrace it passionately (Katz, 2017). Tushman \& Anderson (2014), further allude that technological innovation sets the stage within which organizations compete. Firms compete to prevail in a particular context, but also to shape the competitive context itself.

According to Fitzroy et al. (2012), the rise of the information economy has already brought profound change in almost every aspect of economic life. This digital revolution is far from over, and the networking economy will become allpervasive. Not only will this and other technologies create opportunities for new markets and products; they will also demand new competencies. In earlier eras, firms could achieve great success by responding to pre-existing wants and needs. In the 21st century, technologies change will increasingly require that firms will have to create markets and market opportunities, a quite different challenge. The ability to innovate is central to the longer-term challenge of creating firm value, (Damanpour, F., Evan, W.M., 2014).

\section{Methodology}

A descriptive research was adopted, because it provided a means to contextually interpret and understand the impact of independent variables on dependent variables. According to Brychan (2016); a descriptive study describes the existing conditions and attitudes through observation and interpretation techniques. The target population for this study was 64 staff including the heads of departments, senior managers and managers in the functional and divisional levels. A census was conducted since the population numbers was quite small. Primary data was collected using. The data collected was first captured in Microsoft Excel, checked for completion and coded and then analyzed quantitatively using percentages, frequencies and using linear regressions. Descriptive and inferential statistics were used to assess the determinants of competitive advantage for manufacturing firms in Rwanda. Statistical Package for Social Scientists was used to execute multiple linear regressions. The multiple linear regression that was used to analyze the findings is $Y=$ $\beta_{0}+\beta_{1} X_{1}+\beta_{2} X_{2}+\beta_{3} X_{3}+\varepsilon$. The results were presented using figures and tables for ease of understanding.

\section{Results and Findings}

\subsection{Effect of Innovation on Competitive Advantage of Africa Improved Foods}

As per the first objective of this study; the researcher sought to assess the effect of innovation on competitive advantage of Africa Improved Food in Rwanda, the researcher evaluated different variables related to innovations. These include new products development, more expenditure in Research and development and new capabilities. The findings are presented here below: The results in Table 1 indicate that $67.2 \%$ of respondents strongly agreed that Africa Improved Food develops new products and launches them to new markets, $28.1 \%$ of respondents agreed that Africa Improved Food develops new products and launches them to new markets, 3.2\% of respondents disagreed that Africa Improved Food develops new products and launches them to new markets while only $1.6 \%$ of respondents were neutral to the statement. As revealed by the findings; the majority of respondents confirmed that Africa Improved Food does innovations by developing new products and launches them to new markets.

A business exists to satisfy customers while making profit. Fundamentally, a firm fulfills this dual purpose through its products. New-product planning and development are vital to an organization's success. This is particularly true, which is now given as rapid technological changes, which can make some products obsolete, and the practice of many competitors to copy a successful product, which can neutralize an innovative product's advantage (Veryzer, 2013).

\begin{tabular}{|c|c|c|}
\hline Level of Agreement & Frequency & Percentage \\
\hline Strongly Agree & 43 & 67.2 \\
\hline Agree & 18 & 28.1 \\
\hline Disagree & 2 & 3.2 \\
\hline Neutral & 1 & 1.6 \\
\hline Total & 64 & 100.0 \\
\hline
\end{tabular}

Table 1: Development of New Products to New Markets

\subsection{Development of New Products to Existing Markets}

The findings in Table 2 show that 75\% of respondents strongly agreed that Africa Improved Food develops new products and launches them to existing markets, $18.7 \%$ of respondents agreed that Africa Improved Food develops new products and launches them to existing markets, $6.3 \%$ of respondents were neutral to the statement.

Successful product development results in products that can be produced and sold profitably, yet profitability is often difficult to assess quickly and directly (Ulrich and Eppinger, 2015). Five dimensions, all of which ultimately relate to profit, are commonly used to assess the product specifications (Dahan and Houser, 2010).

\begin{tabular}{|c|c|c|}
\hline Level of Agreement & Frequency & Percentage \\
\hline Strongly Agree & 48 & 75 \\
\hline Agree & 12 & 18.7 \\
\hline Neutral & 4 & 6.3 \\
\hline Total & 64 & 100.0 \\
\hline
\end{tabular}

Table 2: Development of New Products to Existing Markets 


\subsection{Developing New Capabilities to Compete at the Market}

The findings in Table 3 demonstrate that $78.1 \%$ of respondents strongly agreed that Africa Improved Food develops new capabilities that enable to compete at the market, $20.3 \%$ of respondents agreed that Africa Improved Food develops new capabilities that enable to compete at the market while $1.6 \%$ of respondents were neutral to the statement.

\begin{tabular}{|c|c|c|}
\hline Level of Agreement & Frequency & Percentage \\
\hline Strongly Agree & 50 & 78.1 \\
\hline Agree & 13 & 20.3 \\
\hline Neutral & 1 & 1.6 \\
\hline Total & 64 & 100.0 \\
\hline
\end{tabular}

Table 3: Developing New Capabilities to Compete at the Market

\subsection{Descriptive Statistic of Innovation on Competitive Advantage of Africa Improved Foods}

According to the results from Table 3; the mean values for 3.5926; are respectively Innovation strategies of Africa Improved Foods, Innovation strategies on competitive advantage of Africa Improved Foods with mean 3.3056, Creativity of new product on competitive advantage of Africa Improved Foods with mean of 3.3704 and The demand of new products based on innovative Technics at Africa Improved Foods with 3.75.

\begin{tabular}{|c|c|c|c|}
\hline & $\mathbf{N}$ & Mean & Std. Deviation \\
\hline Innovation strategies of Africa Improved Foods & 64 & $\begin{array}{c}3.592 \\
6\end{array}$ & 1.02344 \\
\hline $\begin{array}{c}\text { Innovation strategies on competitive advantage of Africa Improved } \\
\text { Foods }\end{array}$ & 64 & $\begin{array}{c}3.305 \\
6\end{array}$ & 0.99961 \\
\hline $\begin{array}{l}\text { Creativity of new product on competitive advantage of Africa } \\
\text { Improved Foods }\end{array}$ & 64 & $\begin{array}{l}3.370 \\
4\end{array}$ & 1.01016 \\
\hline The demand of new products based on innovative & 64 & 3.75 & 0.99649 \\
\hline \multicolumn{4}{|l|}{ Technics at Africa Improved Foods } \\
\hline Correlation between innovation and competitive advantage of AIF & & & \\
\hline
\end{tabular}

Table 4: Descriptive Statistic of Innovation on Competitive Advantage of Africa Improved Foods

According to findings in the Table 5, the results of correlation between innovations and competitive advantage of Africa Improved Food is at the level of 0.789 meaning that the practice of making innovations which is measured in terms of developing new products to new markets, developing new products to existing markets, spending money is Research and Development and developing new capabilities to compete at the market influence the Return on investment, Market Share and Profitability of Africa Improved Food at the level of 78.9\%. Therefore, the study infers that a strong relationship between innovations and competitive advantage of Africa Improved Foods. By considering the level of significance which is 0.05 , there is a significant relationship innovations and competitive advantage of Africa Improved Foods as their p-value (0.007) is statistically significant at $5 \%$ level of significance.

\begin{tabular}{|c|c|c|c|}
\hline & & Innovation & Competitive Advantage \\
\hline Innovations & Pearson Correlation & 1 & $.789^{* *}$ \\
& Sig. (2-tailed) & & 007 \\
& $\mathrm{~N}$ & 64 & 1 \\
Competitive & Pearson Correlation & $.738^{* *}$ & 64 \\
Advantage & Sig. (2-tailed) & .007 & 64 \\
\hline
\end{tabular}

Table 5: Correlation between Innovation and Competitive Advantage of AIF

\section{Discussions}

These results are consistent with previous research. For instance, Mohen, P. and Hall, B. H. (2013) found a positive and significant relationship between product differentiation strategy and organizational performance. These findings also support the works of Marques et. al., (2012), Silva, (2014) and Waheed, A. (2012) which showed that organizations following a differentiation strategic choice tended to achieve higher performance relative to those organizations which did not. Similarly, Murage (2011) in his study on the competitive strategies used in the Africa improved foods found that service stations used differentiation as a way of obtaining competitive advantage over other service stations. The results of the study also concur with that of Kimotho (2012) which studied competitive strategies on the financial performance of CFC Stanbic Bank Limited and found that the companies that are effective at rapidly innovating new products gained a competitive edge over their rivals 


\section{Conclusions and Recommendations}

According to the interpretation of collected and analyzed data during the course of this study the researcher came up with the following conclusions:

\subsection{The Effect of Innovation on Competitive Advantage of Africa Improved Food}

Africa Improved Foods become superior in manufacturing companies where its markets volumes increased on high levels according to the view of researcher in this research. For instance based on its financial statement, gross profit margin in 2016 was $0.57 \%$, in 2017 it gradually increased to $0.67 \%$ while 2018 it tremendously increased to $0.87 \%$, more of this the situation indicated that they was increased in performance of Africa Improved Foods, furthermore also its net profit margin in 2016 was $0.8 \%$, in 2017 it became $0.84 \%$ whereas 2018 the net profit margin surprisingly became $0.87 \%$. Therefore, innovation on competitive advantage has staidly helped Africa Improved Foods toward its growth.

In regard to manufacturing firms in Rwanda; especially Africa Improved Foods Ltd should take the innovative spirit to the highest level by increasing the efforts in new products development, markets development and invest more money in research and Development so as to outperform its competitors. Incremental innovation doesn't just apply to products; it affects services too. Africa Improved Foods's has evolved its delivery service so that online shoppers can receive their goods more quickly. This strategy could immediately affect positively the market structure of Africa Improved Foods.

\section{References}

i. Abdallah, G. M. Al, \&Muala, A. Al., (2012). Impact of Innovation on Realizing Competitive Advantage in Banking Sector in Jordan. American Academic \& Scholarly Research Journal.

ii. Andreanne and Swaminathan, (2017). Organizational innovation: a meta-analysis of effects of determinants and moderators. Academy of Management Journal 34 (3), 555-590.

iii. Bayarçelik, E. B., Taşel, F., \&Apak, S., (2014). A Research on Determining Innovation Factors for SMEs.Procedia Social and Behavioral Sciences, 150, 202-211.

iv. Brychan, (2016).Business research methods.

v. Crepon et al., (2014).Research and Development, Innovation and Econometric Analysis at the Firm Level. Economics of Innovation and New Technology, 7(2), 115-58

vi. Cottam, Ensor \& Band, (2016). Innovation is not enough: Climates for initiative and psychological safety, process innovations, and grim performance. Journal of Organizational Behavior 24, 45-68.

vii. Chuck Schamark, (2017). Entrepreneurship: globalization, innovation and development. Thomson.

viii. Della and Grafman, (2013). Measuring innovative performance: is there an advantage in using multiple indicators? Research Policy 32, 1365-1379.

ix. Damanpour, F., (1990). Innovation effectiveness, adoption and organizational performance.

X. Damanpour, F., Evan, W.M., (2014). Organizational innovation and performance: the problem of 'organizational lag'. Administrative Science Quarterly 29 (3), 392-409.

xi. Dahan and Houser, (2010). Human Resource Development of Professionals in an Emerging Economy: The Case of the Tanzanian Construction Industry. International Journal of Human Resource Management17, 3, 440 -463.

xii. Fitzroy et al. (2012). Questioning two myths in innovation literature'. Journal of High innovation

xiii. Fritsch, M. and Mueller, P. (2014). Innovation and competitive advantage. Working Paper No. 159, OECD, Paris.

xiv. Germain, R., (2016). The role of context and structure in radical and incremental logistics innovation adoption. Journal of Business Research, 35 (2), 117-127.

xv. Griffith et al. (2012). The Role of the Region for Innovation Activities of SMEs. European Urban and Regional Studies, 8(3), 203-215.

xvi. Kimotho (2012). Innovation and Industry Evolution.

xvii. Katz, (2017). The human side of managing technological innovation: A collection of managerial for innovation.

xviii. Kumlu, Ö., (2014). Innovativeness and performance: Evidence from manufacturing sectors. Journal of Strategic Marketing 12 (4), 255-266.

xix. Lucia, (2012). Competitive strategies by commercial banks in Kenya. Unpublished MBA

xx. Legros\&Galia. (2012). Are innovation and R\&D the only sources of firms' knowledge that increase productivity? An empirical investigation of French manufacturing firms.Journal of Productivity Analysis 38 (2): 167-181.

xxi. Les Robinson, (2014). Strategic Management: Theory and application. Oxford its implications on firm financial performance: An empirical discussion. International

xxii. Muscio, A., Nardone, G., \& Dottore, A., (2010). Strategic management: The challenge of creating value. Routledge.

xxiii. Morgan, E. J., \& Crawford, N., (2003). A demand-based perspective on sustainable competitive advantage.

xxiv. Mohen, P. \& Hall, B. H. (2013). SMEs innovative capacity, competitive advantage and performance in a 'traditional' Industrial region of Portugal. Journal of Technology Management and Innovation

xxv. Marques at al. (2012). Innovation and the performance of Portuguese business: a 'SURE' approach. International Journal of Management and Enterprise Development 10 (2/3): 114-128.

xxvi. Murage (2011). Building Systemic Competitiveness: Concept and Case Studies from Mexico, Brazil, Paraguay, Korea and Thailand. German Development Institute.

xxvii. Miles and Huberman, (2014). Understanding demand for innovation in the food industry. 
xxviii. OECD, (2014). Trustworthiness as a source of competitive advantage, Strategic. Management

Journal. 15, pp. 175-190.

xxix. MINECOFIN, (2013). Economic Development and Poverty Reduction Strategy II: 2013-2018.

xxx. Mairesse\& Robin. (2014). Using innovation survey for econometric analysis. in Hall, B.

xxxi. OECD, (2005). Oslo Manual. Guidelines for Collecting and Interpreting Technological Innovation Data.

xxxii. Porzingis, (2016). The effects of human resource management practices on productivity: a study of steel finishing lines. , American Economic Review 87,3,291-313.

xxxiii. Rogers (2016). Firm resources and sustained competitive advantage. J Manage 1991; 17: 99-120.

xxxiv. Schumpeter's, (2010). Capitalism, Socialism and Democracy. Harper\& Row, New York.

xxxv. Saunila, M., (2014). Innovation capability for SME success: perspectives of financial and operational performance. Journal of Advances in Management Research, 11(2), 163-175.

xxxvi. Silva, (2014). Sources of information as determinants of novelty of innovation in manufacturing firms: Evidence from the 1999 statistics Canada innovation survey. Technovation, $\quad$ 25(3)245-259. 124

xxxvii. Tushman \& Anderson, (2014). Managing strategic innovation and change: A collection of readings. Oxford University Press, USA.

xxxviii. Ulrich and Eppinger, (2015). Determinants of innovation in small food firms. European Journal of Innovation Management, 6(1), 8-17.

xxxix. Van Stel, A. (2013). Empirical Analysis of Entrepreneurship and Economic Growth. International Studies in Entrepreneurship, Springer.

xl. Veryzer, (2013). The impact of government R\&D subsidies on SMEs in Korea: Do government R\&D subsidies make SMEs more competitive in the market.

xli. Von stamm, (2018). Managing innovation, design and creativity. John Wiley \& Sons.

xlii. Wang, Y., \& Costello, P., (2009). An Investigation into Innovations in SMEs: Evidence from the West Midlands, UK. Journal of Entrepreneurship, 18(1), 65-93.

xliii. Waheed, A. (2012) Factors determining the Innovative ability of manufacturing SMEs in Nigeria

xliv. Zhang, M., (2006). Conceptualizing the Learning Process in SMEs: Improving Innovation through External Orientation. International Small Business Journal, 24(3), 299-323.

xlv. Zemplinerova \& Hramadkova. (2012). Determinants of Firm's Innovation. Prague Economic Papers, 4: 487-503. 